\title{
Relationship Of Teacher Example In The Formation Of Characters Of Students
}

\author{
Saliman $^{1}$, Sudrajat ${ }^{2}$, Y Hartati ${ }^{3}$ \\ 1,2, 3 Social Sciences Education, Yogyakarta State University, Indonesia \\ salimanjaper@uny.ac.id ${ }^{1}$,sudrdajat@uny.ac.id²,yumihartati@uny.ac.id ${ }^{3}$
}

\begin{abstract}
Strengthening character education as mandated by the law has not been able to answer the nation's problems, namely the growth of noble character as the main Indonesian people. In fact there are still many educational institutions that have not succeeded in shaping the character of students. Therefore, the teacher's exemplary level in the formation of the character of the students is absolutely to be studied so that it can be seen the relationship between the example with character formation. This study aims to determine the relationship between teacher exemplary in character building junior high school students in DIY. This research is a type of correlation research. The subjects of this study were 208 junior high school DIY teachers. Data collection techniques: questionnaire. Data analysis uses quantitative analysis. Data analysis techniques using inferential statistics. The results of this study indicate a significant positive correlation coefficient between teacher exemplary in the character formation of students is equal to $(r)=0.472$ accompanied by a significance of 0,000 , so that exemplary increases, it will be accompanied by an increase in the character formation of students. Correlations that occur are in the moderate category $(0.472)$.
\end{abstract}

Keywords: relationship, exemplary, character building.

\section{Introduction}

In the last few decades, there has been a new trend where the awareness of values has begun to grow again. This tendency occurs globally and can be described as a turning point in the development of human civilization. People began to talk about values, even for fields that were considered free of values such as science and technology. The next turning point that places issues of value as the focus of attention is the growing popularity of emotional intelligence and spiritual intelligence. Indonesia began to develop education and teaching that integrates science and technology with aspects of faith and devotion to God Almighty. At the same time schools are trying to create a climate that is conducive to the growth of values, moral and religious awareness for their students.

Character education becomes the prima donna program offered by various educational institutions both at primary and secondary levels. However, unfortunately, the strengthening of character education as mandated by the law has not been able to answer the serious problem faced by this nation, namely the growth of noble character as the main Indonesian people. But in reality, there are still many educational institutions that have not succeeded in shaping the character of students. This is proven by the fact that there are still students who are lazy to worship, lie, lack discipline, lack interest in reading, not polite, care less about the environment and so on. Even though almost all education units have implemented character education, there are no signs of improving the quality of Indonesian human characters in a better direction. Increasingly widespread corruption, a crime that is still rampant, violence and 
narcotics abuse still always heard in the news in the mass media. Therefore, the teacher's exemplary level in the formation of students' character in the absolute education unit to be examined to see the relationship between the model and character education.

When President Joko Widodo and Vice President Jusuf Kalla launched Nawacita, character education was a concrete implementation of the program in the field of education integrated with the National Movement for Mental Revolution, namely a change in the way of thinking, acting and acting for the better. Strengthening Character Education (PPK) carries the main values to be inculcated and internalized into students so that they become a superior gold generation in the future. Character values in KDP are religious, nationalist, independent, cooperation, and integrity. To strengthen and provide a legal umbrella for KDP policies, Presidential Regulation No. 87 of 2017 concerning the strengthening of character education. This is felt to be very urgent given the increasingly severe challenges for life in the future marked by changes in the social and cultural fields. This was also based on the erosion of the positive character of the Indonesian people, which was marked by the increasingly widespread corruption, brawl, persecution, spreading false news, and others.

There are ten indicators of the nation heading for destruction, namely: 1) increased violence among adolescents; 2) use of bad language and words; 3) strong influence peer group in acts of violence; 4) increased self-destructive behaviour, such as drug use; alcohol and free sex; 5) blurring of good and bad moral guidelines; 6) decreased work ethic; 7) lower respect for parents and teachers; 8) low sense of responsibility as individuals and as citizens; (9) culture of dishonesty and 10) mutual distrust and hatred [1]. This phenomenon has become a common sight in Indonesian society. Drugs, free sex, violence, and lies have damaged the values, ethics, character and morality of the nation which need to be resolved immediately if it still wants the establishment of this beloved Indonesian nation. The development of values, morals, and religions is increasingly being recognized as an urgent need considering that cognitive intelligence alone does not guarantee one's success in life. Therefore, building a balance between cognitive, affective, and psychomotor aspects on an ongoing basis is the highest educational value.

Education is an upright pillar of a nation, through education a nation will be able to maintain its dignity. Education is held to free people from the various problems of life that surround them. Education is one of the efforts to restore the function of humans to become humans to avoid various forms of oppression, ignorance to backwardness. Education must be placed as a liberation tool to deliver humans into moral and dignified beings [2]. The mental condition of our young generation has begun to decline, so we need to find a way out so that this nation does not lose the next generation of its people. The search for the best alternative to improve the quality of our young generation needs to be sought. One of the best efforts we can do is to re-function educational institutions properly. Inculcation of noble character needs to be done through education channels, especially formal education.

Educational institutions as a place to grow the ethics, mindset and morals of students to a better level with a good way or process also need to be empowered so that it can function as a vehicle for social and cultural transformation. At the basic level of education, the implementation of character education is carried out by referring to the Strengthening Book of Elementary and Middle School Level Secondary Education, published by the Ministry of Education and Culture of the Republic of Indonesia in 2017. The guidelines explain that the KDP movement focuses on the structures that already exist in the education system national. Three structures can be used as a vehicle, pathway, and medium to strengthen national character education, namely: First, the Program Structure, including levels and classes, school ecosystems, strengthening teacher capacity; Second, Curriculum Structure, including 
character-building activities that are integrated with learning (extracurricular), curricular, and extracurricular; Third, the Activity Structure, among others, various programs and activities that can synergize the four dimensions of character processing from Ki Hadjar Dewantara (sports, mind thinking, taste processing, and heart processing). Character education is everything that is done by the teacher to influence the character of students. The teacher helps and shapes the character of students by giving examples, ways of speaking or delivering good material, tolerance, and various other related matters.

It seems that schools in Indonesia do not seem to have the magical power to shape the character of each student through the curriculum being taught. Pessimistic with our schooling system, it could be, but we must not be complacent and must rise. This is where and when character education is formulated to advance Indonesian education. Various forms of innovation and reform have been engineered, starting from the learning system, curriculum, scholarship for student teachers and up to "standardized schools" in various forms. But it has not been able to bring forth the reliable character of students. The results of our education seen today are still thick at the cognitive level has not touched the aspects of character with an honest, trustworthy, tough and competitive morality [3]. This can be seen from the rise of the phenomenon of clits that emerged in Yogyakarta, which is generally done by teenagers in their teens (school age). "Klitih phenomenon" is a phenomenon of juvenile delinquency which is rife in Yogyakarta which is generally carried out by teenagers who are still sitting in junior high school. KRJOGJA.com December 28, 2018 edition contains the article that some residents of Yogya began furiously about the rise of "clitih" acts carried out by teenagers. In Bantul, residents arrested two Klitih people, namely Rn (16) residents of Padokan Lor, Tirtonirmolo, Kasihan, Bantul and Wa (16) residents of Kembaran, Tamantirto, Kasihan, Bantul while doing mischief in an area on Jalan Bibis Dusun Gendeng, Bangunjiwo, Kasihan, Bantul, Wednesday (12/26) morning. From the hands of the two perpetrators, the police secured iron sticks and swords. Until Thursday (12/27), both of them have been detained and named suspects (https://krjogja.com/web/news/read/87173/ Geram_Asisi_Klitih_Parga Turun_Tangan downloaded on 3 January 2019). News about "klitih" is also contained in KRJOGJA.com 12 December 2019 edition, 18 July 2019, 13 July 2019. The term "klitih" refers to activities that describe the form of adolescent anarchism that is rife in Yogyakarta. "Klitih" is identical to youth or a group of young men who want to hurt or paralyze their opponents with violence using sharp weapons such as knives, swords, gears and others.

Some of the phenomena of juvenile delinquency (school-age children) are one indication that the achievement of educational goals has not been achieved relationship must be established holistic that good between the teacher and students. A teacher has duties and obligations in shaping the character of students through exemplary. Exemplary has a very important meaning in the activities of the educational process. Ideally, if the teacher has a good temperament, students will have the same thing, and vice versa. A teacher should be able to be a role model for his students, not only have the obligation to deliver the subject matter but can be able to show good speech, behaviour, and appearance so that it can be emulated in everyday life.

Methods that can be applied for character education are grouped into four, namely the inculcation of values, exemplary values, value facilitation, and value skills. Each method has various strategies for its implementation [4]. Exemplary becomes important in overcoming character problems and has a major contribution in educating and fostering character. Example exemplifies behavioural aspects in the form of concrete actions rather than just speaking. Exemplary strategies or methods in character building become part of a comprehensive approach that is a synthesis of two traditional methods, namely: (1) the inculcation (planting) 
method of value by setting an example; and (2) contemporary methods with value facilitation through life skills (live skills) [5]. Based on this the researcher believes that the teacher's role model also determines the character formation of students. Based on facts on the ground, as well as existing ideas and thoughts, the researcher is interested and sees the need to reveal the exemplary relationship of teachers in shaping the character of junior high school students in the Special Region of Yogyakarta.

\section{Method}

Based on the problem studied, this type of research belongs to the type of correlation research. This research is substantially the type of correlation research used to explain the relationship between teacher exemplary variables in shaping the character of junior high school students in the Special Region of Yogyakarta. The population in this study were teachers, principals and junior high school students in the Special Province of Yogyakarta, as many as 212 people. Based on population data, 136 people were determined stratified random sampling determined the number of samples as follows: Bantul as many as 20 people, Gunung Kidul 30, Kulon Progo 20, Sleman 30, and the city of Yogyakarta as many as 12 people.

Analysis of the data that the authors used in this study used quantitative analysis and tested its relationship with product-moment correlation. Data analysis techniques in quantitative research use statistics. Inferential statistics (inductive statistics) are statistical techniques used to analyze sample data and the results are applied to the population in this study. The data analysis technique used to determine the teacher exemplary relationship in forming the character of junior high school students uses correlation statistics.

\section{Results And Discussion}

Exemplary is a commendable behaviour by the values of truth and goodness. The way that can be implemented by educators is by adjusting the example to the students in terms of the embodiment of the character. In addition to the teacher's task of educating students academically, but have other responsibilities, namely to be a source of inspiration and can motivate to learn so that they can realize their ideas as the next generation of the nation. Exemplary behaviour should be owned by adults who are located in an educational environment such as teachers, principals, staff and school committees. So that the exemplary process occurs, in this case, the teacher to the students in terms of character building.

The characters that each student has are different because the characters are psychiatric and moral. So that by looking at the character of a student can show personality by seeing the commendable and despicable act of a student. Character is character education, morals, values, and character education which has the goal of being able to improve the ability of students in terms of making good and bad decisions, maintaining what is good, and realizing that goodness in everyday life with all my heart [6].

So that character education is everything that is carried out by the teacher in terms of affecting the character of students. The teacher can help and shape the character of students by giving examples, ways of speaking or delivering good material, tolerance, and various other related matters. Character education in schools is strongly influenced by teacher behaviour because teachers deal directly with their students. Negative teacher behaviour can kill a child's 
character (angry/fierce, less caring, make children feel inferior, embarrass the child in front of the class, etc.). The positive teacher behaviour, for example, often gives praise, affection, fair, wise, friendly, and polite [7]. Based on the results of the research that has been carried out, the following is the overall teacher character data for the DIY region.

\begin{tabular}{clll}
\multicolumn{4}{c}{ Table 1. Teacher Character Categories in DIY } \\
\hline No & Wilayah & $\begin{array}{l}\text { Rata- } \\
\text { rata }\end{array}$ & kategori \\
\hline 1 & Bantul & 14,74468 & sedang \\
2 & Gunungkidul & 15,55932 & sedang \\
3 & Yogyakarta & 15,97222 & sedang \\
4 & Kulon Progo & 16,16670 & sedang \\
5 & Sleman & 16,03333 & sedang \\
\hline
\end{tabular}

Based on table 1. Categories the teacher's character in DIY can be seen that from overall for the DIY region the teacher's character is in the medium category (15.70673). Based on this the teacher's character can be exemplary to students in the medium category. Exemplary teachers can provide good examples for students, if teachers want students to have a disciplined attitude and behave well, then the teacher should first have a disciplined attitude and behave well too like coming on time, having courtesy, saying softly, doing activities that positive and so on. The essence is that the teacher's example is a very big influence on the personal growth and development of students. This is understandable because humans are creatures who like to imitate, including students imitating the personal teacher in the process of personal formation. Teachers should have good character by being shown in behaviour. So, in applying the example, it must start from yourself, so that students can imitate the good deeds done by the teacher. The social challenge is that the high position of the teacher in the community is the realization of glorifying science, with knowledge the prospective educator who teaches should be able to set an example and set a good example. Therefore, an important factor in educating is located in "exemplary". This example is not just giving an example in doing something, but it can also involve a variety of things that can be emulated, including daily habits which are examples of the teacher's example.

Human needs for exemplary figures stem from the tendency to imitate, which has become a human character. Impersonation comes from the mental state of someone who always feels that he is in the same feelings as other people. Therefore students need figures to emulate and emulate in schools, one of which is the teacher. The teacher can be used as one of the ideal examples in the view of children whose behaviour and courtesy will be consciously or unconsciously imitated, and even all those examples will cling to themselves and their feelings in the form of words, actions, material, worldly and spiritual things. Therefore the example of a teacher in the school environment is one of the determinants of the good and bad of students. If a teacher can be trusted, do good, love the motherland, be brave and do not act immoral, then most likely students can grow with good character. Conversely, if a teacher as a liar, a traitor to the country, does not love the country, the participants will likely grow up with such despicable nature. Therefore it is necessary to look at the teacher's exemplary relationship in shaping the character of students in junior high schools in Yogyakarta, with the following data: 
Table 2. Table Interpretation of Correlation Coefficient

\begin{tabular}{ll}
\hline Interval Koefesien & Tingkat Hubungan \\
\hline $0,00-0,199$ & Sangat lemah \\
$0,20-0,399$ & Lemah \\
$0,40-0,599$ & Sedang \\
$0,60-0,799$ & Kuat \\
$0,80-1,000$ & Sangat Kuat \\
\hline Sumber: $[8]$ & \\
\hline
\end{tabular}

Based on the results of the analysis it can be said that the correlation coefficient between the teacher's exemplary relationship in the formation of students' character is Pearson Correlation $(r)=0.472$ accompanied by a significance of 0.000 and based on the decision criteria above, it can be concluded that the correlation of the two variables is significant, because the accompanying significance is less than $0.05(0.000<0.05)$. Correlations that occur are positive, meaning that when the teacher's example increases, it will be accompanied by an increase in the character of students. Based on the table above, the Pearson Correlation "r" result above turns out to be a value of 0.472 between $0.40-0.599$. Thus, there is a moderate relationship between the teacher's exemplary relationship in the formation of students' character. The next step is to look for the amount of contribution or contribution of the teacher's example in the formation of students' character by the formula:

$\mathrm{KP}=\mathrm{r}^{2} \times 100 \%$

$\mathrm{KP}=0.472^{2} \times 100 \%$

$\mathrm{KP}=22.29$

This means that the importance of teacher exemplary variables in shaping student character is $22.29 \%$. Based on this, various forms of innovation are needed and reforms have been engineered starting from the learning system, curriculum, scholarships and teacher competency improvement. Exemplary teacher is a form of exemplary attitude carried out by the teacher which has a great influence on the personal growth and development of students. Exemplary has a very important role and function in shaping the personality of children, in order to prepare and develop Human Resources (HR), as well as the welfare of society, the progress of the country, and the nation in general [9]. So that it will be able to produce reliable characters of students. Thus education in Indonesia is seen today not only at the cognitive level but needs to be able to touch aspects of character with honesty, trustworthy, tough and competitive morality.

\section{Conclusions}

Hypothesis analysis proves that there is a relationship between the teacher's example in the formation of students' character. This is evident that the correlation coefficient between the teacher exemplary relationship in the formation of student character is equal to Pearson Correlation $(\mathrm{r})=0.472$ accompanied by a significance of 0.000 and based on the decision criteria above, it can be concluded that the correlation of the two variables is significant, because of the significance accompanying it is smaller than $0.05(0.000<0.05)$. Correlations that occur are positive, meaning that when the teacher's example increases, it will be accompanied by an increase in the character of students. Based on the table above, the Pearson Correlation " $r$ " result above turns out to be a value of 0.472 between $0.40-0.599$. Thus, there 
is a moderate relationship between the teacher's exemplary relationship in the formation of students' character. Exemplary is one of the keys to success in shaping students' character, including the success of a teacher in educating their students. The proverb says that one example is more meaningful than a thousand thousand commands and prohibitions.

\section{References}

[1] Lickona, T.: Educating for character, how our schools can teach respect. respect and responsibility. New York: Bantam Books. pp. 13-18 (1992).

[2] Firdaus M Yunus, Pendidikan berbasis realitas sosial: YB Mangunwijaya-Paulo Freire. Yogyakarta: Logung Pustaka. P.1 (2007).

[3] Syahraini Tambak. Membangun bangsa melalui pendidikan. Yogyakarta: Graha Ilmu. p.39. (2013).

[4] Kirschenbaum, H. 100 ways to enhance values and morality in schools and youth settings. Boston: Allyn and Bacon. P.6 (1995).

[5] Widyaningsih, T. S., Zamroni \& Zuchdi, D.“'Internalisasi dan aktualisasi nilai-nilai karakter pada peserta didik smp dalam perspektif fenomenologis”. Jurnal Pembangunan Pendidikan: Fondasi dan Aplikasi, Vol. 2, No. 2, p.189. (2014).

[6] Syafaruddin. Asrul \& Mesiono: Inovasi pendidikan (suatu analisis terhadap kebijakan baru pendidikan). Medan: Perdana Publishing, pp. 178 (2015).

[7] Jejen Musfah. Pendidikan holistik. Jakarta: Kencana. P.147. (2012).

[8] Sugiyono. Metode Penelitian Kuantitatif Kualitatif dan R\&D. Bandung: Alfabeta. P. 184. (2017)

[9] Mulyasa. 2013. Manajemen Pendidikan Karakter. Jakarta: Bumi Aksara. P.1 (2013) 